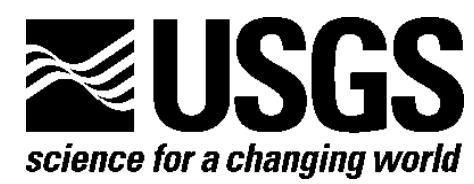

\title{
Emergency Assessment of Post-Fire Debris-Flow Hazards for the 2013 Rim Fire, Stanislaus National Forest and Yosemite National Park, California
}

By Dennis M. Staley

Open-File Report 2013-1260

U.S. Department of the Interior

U.S. Geological Survey 


\section{U.S. Department of the Interior \\ SALLY JEWELL, Secretary}

\section{U.S. Geological Survey \\ Suzette M. Kimball, Acting Director}

U.S. Geological Survey, Reston, Virginia: 2013

For more information on the USGS-the Federal source for science about the Earth, its natural and living resources, natural hazards, and the environment-visit http://www.usgs.gov or call 1-888-ASK-USGS

For an overview of USGS information products, including maps, imagery, and publications, visit $h$ ttp://www.usgs.gov/pubprod

To order this and other USGS information products, visit $h$ ttp://store.usgs.gov

Suggested citation:

Staley, D.M., 2013, Emergency assessment of post-fire debris-flow hazards for the 2013 Rim Fire, Stanislaus National Forest and Yosemite National Park, California: U.S. Geological Survey Open-File Report 2013-1260, 11 p., 3 plates, http://pubs.usgs.gov/of/2013/1260/.

Any use of trade, firm, or product names is for descriptive purposes only and does not imply endorsement by the U.S. Government.

Although this information product, for the most part, is in the public domain, it also may contain copyrighted materials as noted in the text. Permission to reproduce copyrighted items must be secured from the copyright owner. 


\section{Contents}

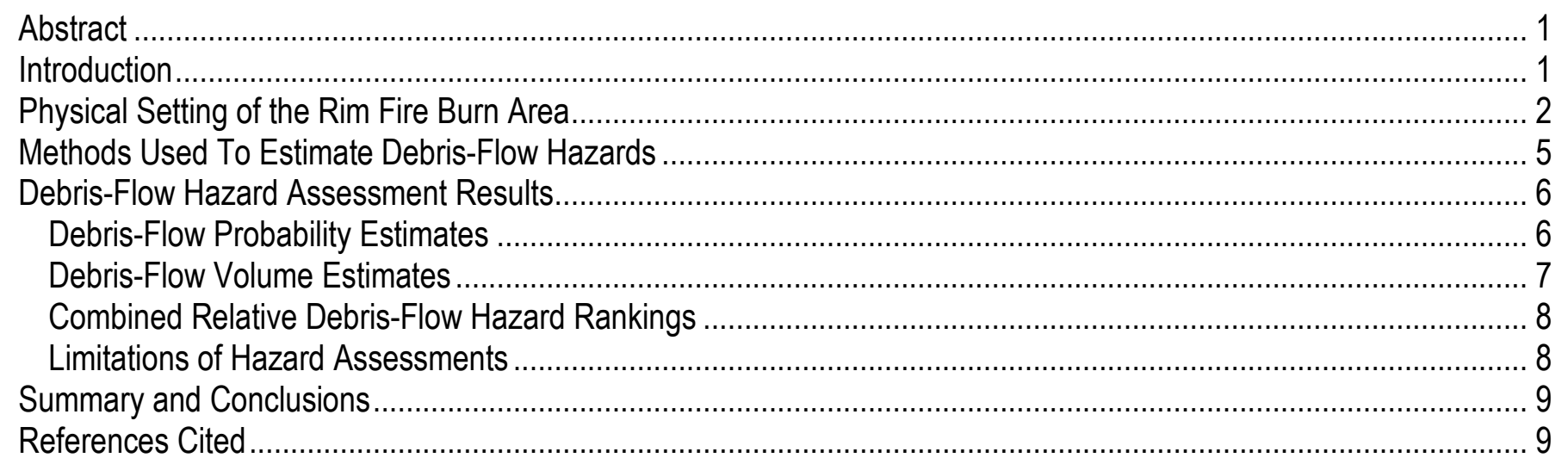

\section{Figures}

Figure 1. Overview map of the Rim fire burn area................................................................................. 3

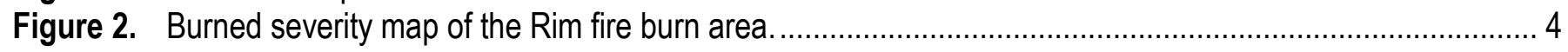

\section{Table}

Table 1. Summary of the total percentage of stream length within each probability, volume, and combined hazard ranking for the Rim fire burn area.

\section{Plates}

Plate 1. Estimated probability of post-fire debris flows in the area burned by the 2013 Rim fire, Stanislaus National Forest and Yosemite National Park, California link

Plate 2. Estimated volume of post-fire debris flows in the area burned by the 2013 Rim fire, Stanislaus National Forest and Yosemite National Park, California . link

Plate 3. Combined relative debris-flow hazard in the area burned by the 2013 Rim fire, Stanislaus National Forest and Yosemite National Park, California . link 


\section{Conversion Factors and Datums}

\begin{tabular}{lcl}
\hline \multicolumn{1}{c}{ Multiply } & \multicolumn{1}{c}{ By } & \multicolumn{1}{c}{ To obtain } \\
\hline millimeter $(\mathrm{mm})$ & 0.03937 & inch (in.) \\
meter $(\mathrm{m})$ & 3.281 & foot $(\mathrm{ft})$ \\
kilometer $(\mathrm{km})$ & 0.6214 & mile (mi) \\
\hline \multicolumn{2}{c}{ Area } & \\
\hline hectare $(\mathrm{ha})$ & 2.471 & acre \\
square kilometer $\left(\mathrm{km}^{2}\right)$ & 247.1 & acre \\
square kilometer $\left(\mathrm{km}^{2}\right)$ & 0.3861 & square mile $\left(\mathrm{mi}^{2}\right)$ \\
square meter $\left(\mathrm{m}^{2}\right)$ & 10.76 & square foot $\left(\mathrm{ft}^{2}\right)$ \\
\hline & Volume & \\
\hline cubic meter $\left(\mathrm{m}^{3}\right)$ & 35.31 & cubic foot $(\mathrm{ft} 3)$ \\
\hline & Flow rate \\
\hline millimeter per hour $(\mathrm{mm} / \mathrm{h})$ & 0.03937 & inch per hour $(\mathrm{in} / \mathrm{h})$ \\
\hline
\end{tabular}

Vertical coordinate information is referenced to the North American Vertical Datum of 1988 (NAVD 88). Horizontal coordinate information is referenced to the North American Datum of 1983 (NAD 83). 


\title{
Emergency Assessment of Post-Fire Debris-Flow Hazards for the 2013 Rim Fire, Stanislaus National Forest and Yosemite National Park, California
}

By Dennis M. Staley

\begin{abstract}
Wildfire can significantly alter the hydrologic response of a watershed to the extent that even modest rainstorms can produce dangerous flash floods and debris flows. In this report, empirical models are used to predict the probability and magnitude of debris-flow occurrence in response to a 10-year rainstorm for the 2013 Rim fire in Yosemite National Park and the Stanislaus National Forest, California. Overall, the models predict a relatively high probability (60-80 percent) of debris flow for 28 of the 1,238 drainage basins in the burn area in response to a 10-year recurrence interval design storm. Predictions of debris-flow volume suggest that debris flows may entrain a significant volume of material, with 901 of the 1,238 basins identified as having potential debris-flow volumes greater than 10,000 cubic meters. These results of the relative combined hazard analysis suggest there is a moderate likelihood of significant debris-flow hazard within and downstream of the burn area for nearby populations, infrastructure, wildlife, and water resources. Given these findings, we recommend that residents, emergency managers, and public works departments pay close attention to weather forecasts and National-Weather-Service-issued Debris Flow and Flash Flood Outlooks, Watches and Warnings and that residents adhere to any evacuation orders.
\end{abstract}

\section{Introduction}

The occurrence of debris flows in response to high-intensity rainfall is well documented in recently burned areas of California (for example, Eaton, 1935; Campbell, 1975; McPhee, 1989; Cannon and others, 2008; 2010; 2011; Cannon and DeGraff, 2009; Kean and others, 2011; Staley and others, in press). Two recent examples highlight the destructive nature of post-fire debris flows. On December 25, 2003, a high-intensity rainstorm initiated debris flows within the Grand Prix and Old burn areas and killed 16 people near San Bernardino, California (Calif.). On February 6, 2010, debris flows produced in the Station fire burn area overtopped sediment-retention basins and damaged or destroyed 46 homes in La Crescenta, Calif. These events provide sobering examples of the threat that post-fire debris flows pose to populations, properties, infrastructure, and important natural resources within and downstream of recently burned steeplands. Although these storms produced high rainfall intensities, they were of a relative high probability with a recurrence intervals under 5 years (yr) (Bonnin and others, 2006).

Wildfire causes numerous changes to the vegetative characteristics and to physical and chemical properties of the soil within a burn area. Reduction in vegetation cover on hillslopes increases soil exposure to rainfall, which can increase erosion caused by rainfall and runoff. Wildfire has also been demonstrated to increase the rate of runoff production by enhancing hydrophobicity in soils through chemical changes and by introducing ash into the soil column (Shakesby and Doerr, 2006; Gabet and Sternberg, 2008; Larsen and others, 2009). These changes ultimately contribute to increases in the rate 
of runoff and erosion during rainfall (Martin and Moody, 2001; Moody and Martin, 2001). The enhanced runoff response permits the initiation of floods and debris flows even during relatively minor rainstorms (Shakesby and Doerr, 2006; Cannon and others, 2008). Post-fire debris-flow hazards further increase in likelihood when the physical and chemical changes introduced in soil during wildfire are combined with steep slopes and an abundant supply of sediment. Given the relatively steep terrain, severity of the wildfire, and proximity of local population and infrastructure, there is an elevated risk of post-fire debris-flow hazards within and downstream of the Rim fire burn area. The purpose of this report is to provide a preliminary assessment of the likelihood and potential magnitude of post-fire debris flows in the area burned by the 2013 Rim fire in Tuolumne and Mariposa Counties, Calif. Published empirical methods (Cannon and others, 2010) that have been previously applied in this region of California (Cannon and Michael, 2011) were used to estimate (1) the probability of debris-flow occurrence in response to a storm with a 10-yr recurrence interval, (2) the predicted volume of material transported and deposited by a debris flow in response to a storm with a 10-yr recurrence interval, and (3) a combined relative-hazard ranking that incorporates the results of the probability and volume models. The models were applied at scale of selected basins and along the drainage network within these basins.

\section{Physical Setting of the Rim Fire Burn Area}

The Rim fire is the third largest fire in California history, burning $1,040 \mathrm{~km}^{2}$ (257,000 acres) of mountainous terrain on the Stanislaus National Forest (154,108 acres) and Yosemite National Park (78,946 acres) in Tuolumne and Mariposa Counties (inciweb.org, 2013). The Rim fire began on August 17, 2013, and had not yet been fully contained at the time of writing (fig. 1). The Rim fire damaged or destroyed 111 structures and cost an estimated $\$ 119$ million as of September 21, 2013. In addition to the direct effects on nearby communities, several important water and wildlife resources are within and downstream of the burn area, including Yosemite National Park, a portion of the Tuolumne River basin, Hetch Hetchy Reservoir, Lake Eleanor, and Cherry Lake.

The area burned by the Rim fire occupies mountainous terrain with elevations ranging from 265 meters $(\mathrm{m})$ to $2,400 \mathrm{~m}$ with an average slope of 35 percent. Slope gradients were bimodal, with topography characterized by gentle gradients on the plateau with steeper slopes situated along canyon walls and where headwaters streams join the larger rivers. A little under half of the area consumed during the fire was burned at low severity (56 percent). Moderately burned areas composed 37 percent of the burn area, whereas 7 percent of the area burned by the Rim fire was identified as having a high burn severity(fig. 2) (Alan Gallegos, U.S. Forest Service, written commun., September 22, 2013). Areas of moderate and high burn severities fall primarily in the central and eastern portions of the burn area, where the topography contains steeper slopes and more dense vegetation.

Precipitation-frequency estimates for the burn area indicate that there is 10-percent likelihood in any given year (that is, a 10 -yr storm event) that 60 -minute (min) rainfall accumulations within the burn area will range between 22.8 millimeters $(\mathrm{mm})$ and $29.0 \mathrm{~mm}(0.9$ and 1.1 inches) (Bonnin and others, 2006). These estimates suggest that a 10 -yr recurrence interval is likely to produce rainfall rates that exceed rainfall intensity-duration thresholds at which post-fire debris flows are known to occur in recently burned areas of southern California and the intermountain western United States (Cannon and others, 2008; Staley and others, in press). However, there are no known rainfall intensity-duration thresholds that have been developed specifically for post-fire debris-flow initiation in the vicinity of the Rim fire. We selected this storm frequency and magnitude as it represents a relatively large magnitude (in terms of total accumulation and peak storm intensities), but still somewhat common rainstorm. 


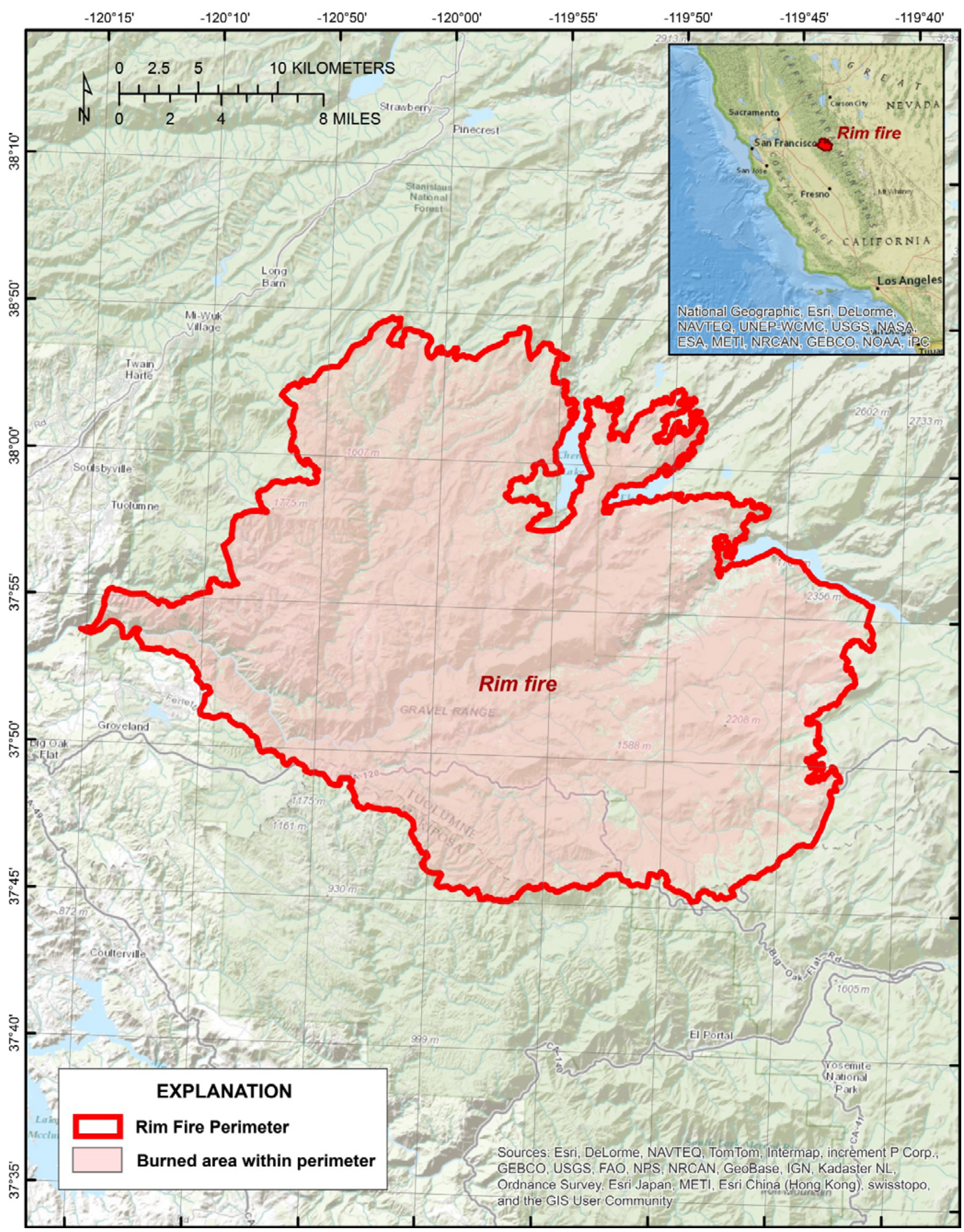

Figure 1. Overview map of the Rim fire burn area. 


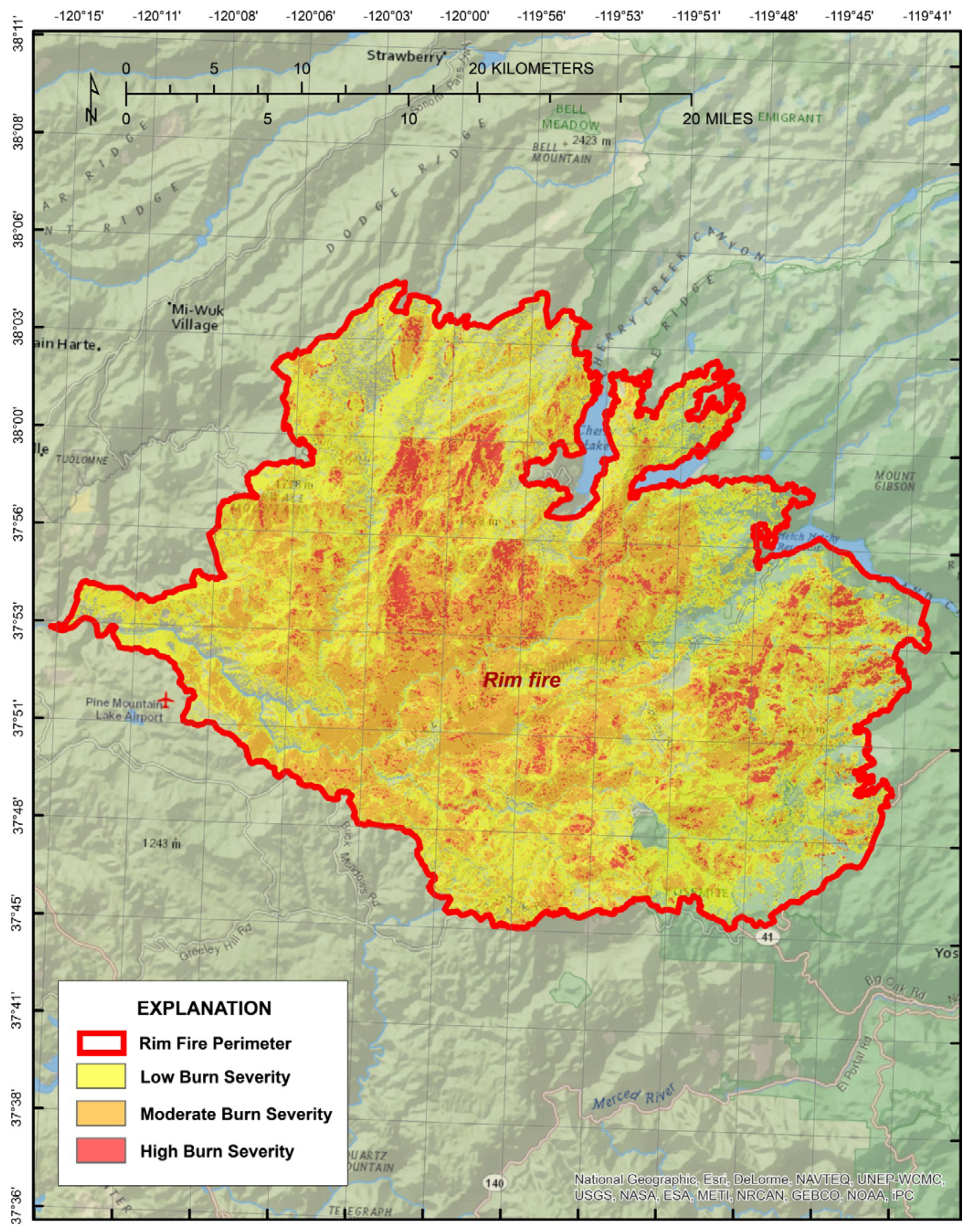

Figure 2. Burned severity map of the Rim fire burn area. 


\section{Methods Used To Estimate Debris-Flow Hazards}

The emergency hazard assessment relies upon two empirical models to estimate the probability and volume. These models are cumulated to define combined relative-hazard ranking of debris flows for selected drainage basins within the Rim fire. In this case, we use a rainstorm with a 10-yr recurrence interval for the design storm. The empirical models are based upon historical debris-flow occurrence data, rainfall storm conditions, terrain and soils information, and burn severity data from recently burned areas in the intermountain western United States (Cannon and others, 2010). The probability database consists of 338 records from 13 burn areas from the years 2003-2010, and the volume database consists of 55 records from 8 burn areas (Gartner and others, 2008; Cannon and others, 2010).

In this study, post-fire debris-flow probability, volume, and combined hazards were estimated both at the drainage-basin scale and along the drainage network within each basin. Basin outlets were identified for 1,238 drainage basins, and the characteristics of their upslope areas were calculated using a geographic information system (GIS). Debris-flow probability and volume were estimated for each basin outlet as well as along the upstream drainage networks (pixels where the contributing area is greater than or equal to $0.02 \mathrm{~km}^{2}$ and no more than $30 \mathrm{~km}^{2}$ ) using a method that has been applied in recently burned areas (for example, Gartner and others, 2011; Tillery and others, 2012; Verdin and others, 2012; Tillery and Matherne, 2013). Estimates of debris-flow probability and volume were obtained for every 10-m pixel along the drainage network (plates 1 and 2) as a function of the distribution of independent variables upstream from each pixel. The technique used here allows for a view of how probability and volume estimates are spatially distributed within the drainage basin.

Probability estimates are based upon a logistic regression model (Cannon and others, 2010). This model is designed to predict the probability of debris-flow occurrence at a point along the drainage network in response to a given storm by combining the following two equations:

$$
P=e^{x} /\left(1+e^{x}\right),
$$

where:

$P \quad$ is the probability of debris-flow occurrence in fractional form, and

$e^{x} \quad$ is the exponential function where e represents the mathematical constant 2.718 .

Equation 2 is used to calculate $x$ :

$$
\begin{gathered}
x=-0.7+\left(0.03 \times S 30_{p c t}\right)-(1.6 \times \text { Ruggedness })+\left(0.06 \times H M_{p c t}\right)+\left(0.07 \times \text { Rain }_{\text {int }}\right)+ \\
\left(0.02 \times C C_{p c t}\right)-(0.04 \times l l)
\end{gathered}
$$

where:

$S 30_{p c t}$ is the percentage of the upstream watershed that has slope values in excess of 30 percent (in percent),

Ruggedness is the range (maximum elevation-minimum elevation) of elevation values upstream of the point (in meters) divided by the square root of the watershed area,

$H M_{p c t}$ is the percentage of the upstream watershed that was burned at high or moderate severity (in percent),

Rain $_{\text {int }}$ is the average intensity of the rainstorm (in millimeters per hour),

$C C_{p c t}$ is the average clay content of the soils in the basin (in percent) (Schwartz and Alexander, 1995), and

$l l \quad$ is the average liquid limit of the soils in the basin (in percent) (Schwartz and Alexander, 1995). 
In this case, we use the 60-min rainfall intensity for a 10 -yr recurrence interval storm (in mm). Probabilities predicted by the equation potentially range from 0 (least likely) to 100 percent (most likely). The predicted probabilities are assigned to 1 of 5 equal ( 20 percent) interval classes for cartographic display.

Debris-flow volumes both at the basin outlet and along the drainage network are predicted using a multiple linear-regression model (Gartner and others, 2008; Cannon and others, 2010). This model is used to estimate the volume of material that could issue from a point along the drainage network in response to a storm of a given rainfall intensity. This model uses the following equation:

where:

$$
\ln V=7.5+\left(0.7 \times \sqrt{H M_{k m}}\right)+\left(0.6 \times \ln \left(S 30_{k m}\right)\right)+\left(0.2 \times \sqrt{\operatorname{Rain}_{a c c}}\right)
$$

$H M_{k m}$ is the area upstream of the calculation point that was burned at high or moderate severity $\left(\right.$ in $\left.\mathrm{km}^{2}\right)$,

$S 30_{\mathrm{km}}$ is the area upstream of the calculation point that has slopes greater than or equal to 30 percent (in $\mathrm{km}^{2}$ ),

and

Rain $_{a c c}$ is the spatially averaged rainfall accumulation (in $\mathrm{mm}$ ) for the design storm in the upstream watershed.

In this case, we use the rainfall accumulations for a 10-yr recurrence interval storm (in mm) with a duration of $60 \mathrm{~min}$. Volume estimates were classified in order of magnitude scale ranges: $0-1,000 \mathrm{~m}^{3}$; $1,000-10,000 \mathrm{~m}^{3} ; 10,000-100,000 \mathrm{~m}^{3}$; and greater than $100,000 \mathrm{~m}^{3}$ for cartographic display.

Locations where contributing areas are in excess of the boundaries of the original models are identified on plates 1, 2, and 3 as a thick dark red line. For these locations, the probability, volume, and combined hazards cannot be estimated. However, flood and debris-flow hazards may be appreciable. These hazardous events are dependent upon debris-flow or flood occurrence in tributary channels. Mainstem channels may be dammed if these tributaries transport large amounts of sediment, vegetation, or debris. Flood or debris flows may propagate through the mainstem channels if these dams breach or if tributaries entrain sufficient material during a debris flow.

\section{Debris-Flow Hazard Assessment Results}

Debris-flow probability, predicted volume, and combined relative hazard were calculated at the outlet of 1,238 drainage basins and their drainage networks located within the Rim burn area. Drainage basin areas range from $0.2-16.4 \mathrm{~km}^{2}$. Debris-flow probability, volume, and combined relative hazard values represent the estimates at the outlet of each drainage basin and for each pixel along the drainage network.

\section{Debris-Flow Probability Estimates}

Overall, the basin-scale model predicts relatively low probabilities ( $0-20$ percent) of debris flow throughout most of the burn area in response to a 10-yr, 60-min rainstorm (plate 1). Low probability values result from the high proportion of slopes that are less than 30 percent throughout the burn area. Higher probability values (60-80 percent) occur within small, steep drainages along canyon walls, mostly within the central portion of the burn area.

Of the analyzed basins, 996 out of 1,238 were identified as having a 0-20 percent likelihood of debris flow during the design storm. These basins mainly occupy plateau-like areas above the rivers. Slightly higher probabilities were calculated for 118 basins, which were determined to have a 20-40 percent probability of debris-flow occurrence. Probabilities of 40-60 percent were calculated for 96 of the basins, and 28 basins were determined to have a 60-80 percent debris flow probability. Probabilities 
were greatest in the smaller drainage basins in the central portion of the burn area, where 28 basins were determined to have a 60-80 percent probability of debris-flow occurrence. No basins were found to be within the 80-100 percent probability classification.

The spatially distributed application of the probability model may be used to identify probability of debris-flow occurrence for specific stream reaches (plate 1). Higher probabilities were found along steeper reaches in close proximity to the larger rivers within the burn area. Table 1 summarizes the total length of stream channel within each probability class.

Table 1. Summary of the total percentage of stream length within each probability, volume, and combined hazard ranking for the Rim fire burn area.

\begin{tabular}{cccc}
\hline Model Class & Class & $\begin{array}{c}\text { Stream Length } \\
(\mathbf{k m})\end{array}$ & $\begin{array}{c}\text { Stream Length } \\
(\%)\end{array}$ \\
\hline Probability & $0-20 \%$ & $5,034.1$ & 84.0 \\
& $20-40 \%$ & 604.6 & 10.1 \\
& $40-60 \%$ & 271.0 & 4.5 \\
& $60-80 \%$ & 81.7 & 1.4 \\
Volume & $80-100 \%$ & 0.3 & 0.0 \\
& & & \\
& $1,000-10,000 \mathrm{~m}^{3}$ & $3,802.7$ & 68.6 \\
& $10,000-100,000 \mathrm{~m}^{3}$ & $1,270.9$ & 22.9 \\
& $>100,000 \mathrm{~m}^{3}$ & 229.0 & 4.1 \\
Combined Hazard Rank & & 240.1 & 4.3 \\
& Low & $4,514.6$ & 82.3 \\
& Moderate & 972.3 & 17.7 \\
& High & 1.4 & 0.0 \\
\hline
\end{tabular}

\section{Debris-Flow Volume Estimates}

Although debris-flow probabilities are relatively low for the area burned by the Rim fire, the volume model revealed that the consequence of debris flows, should they occur, are high since estimated debris-flow volumes are large throughout the burn area (plate 2). We estimated that 88 of the 1,238 basins could produce debris flows with volumes in excess of $10,000 \mathrm{~m}^{3}$. Two basins were estimated as capable of producing debris flows with volumes greater than $100,000 \mathrm{~m}^{3}$ : Ackerson Creek in the eastern portion of the burn area and Granite Creek in the central portion of the burn area.

The spatially distributed volume model identified that large (greater than $10,000 \mathrm{~m}^{3}$ ) debris flows were possible in many stream reaches feeding directly into the larger river systems. Residents downstream should be wary of large amounts of sediment being transported by floods in debris flows in the event that debris flows are initiated during high intensity rainfall. A summary of the total length of channel within each volume class may be found in table 1.

Debris-flow deposition is of particular concern at the location of the Dion Holm powerhouse near the outlet of the Granite Creek watershed. This section was identified as having a 20-40 percent probability of debris-flow occurrence during the design storm (10-yr recurrence interval). Although the probability of debris-flow occurrence is relatively low, there is evidence of historical debris-flow activity at this location. The undated debris-flow deposits in the channel and a high value of estimated volume (greater than $100,000 \mathrm{~m}^{3}$ ) suggest this location is at risk of debris-flow hazards. This location 
has several characteristics that indicate it would be likely to incur deposition in the event of a debris flow. First, the relatively moderate channel slope (12 percent at the powerhouse) is at the upper end of the range of valley gradients where debris-flow deposition is common (Stock and Dietrich, 2003). In addition, the near-perpendicular tributary junction angle with the Tuolumne River is well within the range of junction angles where debris-flow deposition is likely should a debris flow propagate to this tributary junction (Benda and Cundy, 1990).

\section{Combined Relative Debris-Flow Hazard Rankings}

We combined the results of the probability and the volume maps following the methods of Cannon and others (2010) to obtain an estimate of the combined relative hazard of the drainage basins defined for the Rim fire (plate 3). Most of the analyzed basins were within the low relative hazard class, with 939 of the 1,238 of the basins calculated to have a cumulative score of less than 4 out of a possible 9. These low values reflect the relatively gentle gradients (less than 30 percent) composing a large portion of the plateau-like terrain above the major river systems. The remainder of the analyzed basins (300) were calculated as having a moderate hazard ranking, with cumulative scores between 4 and 6 out of a possible 9. The basins are typically larger and slightly steeper than those in the low hazard class, and are found throughout the burn area where headwater streams steepen as they approach the larger river systems. A summary of the total length of stream channel within each hazard class may be found in Table 1.

\section{Limitations of Hazard Assessments}

This hazard assessment used a 10-yr recurrence interval storm to predict the probability, volume, and combined relative hazard of debris flows in basins burned by the 2013 Rim fire in California. Differences in model predictions and actual debris-flow occurrence will arise with differences in actual storm duration and intensity. The models do not account for runoff from snowmelt, snowfall, or rain-on-snow events. The occurrence of snowfall may decrease the probability or volume of potential debris flows, whereas rain-on-snow or snowmelt may increase the probability or volume of potential debris flows.

In addition, this study relies upon readily available geospatial data, the accuracy and precision of which may influence the estimated likelihood and magnitude of post-fire debris flows. However, local conditions (such as debris supply) certainly influence both the probability and volume of debris flows. Unfortunately, locally specific data are not presently available at the spatial scale of the post-fire debrisflow hazard assessment. As such, local conditions that are not constrained by the model may serve to dramatically increase or decrease the probability and(or) volume of a debris flow at a basin outlet. The input geospatial data are also subject to error based upon mapping resolution, elevation interpolation techniques, and mapping and(or) classification methods. Finally, this assessment is specific to debrisflow hazards; hazards from flash-flooding are not described in this study and may be significant.

This assessment also characterizes potential debris-flow hazards at a static point in time immediately following wildfire. Studies of post-fire debris flows in southern California and the intermountain western United States have indicated that debris-flow activity in recently burned areas typically occurs within $2 \mathrm{yr}$ of wildfire (Cannon and Gartner, 2005; Cannon and others, 2008; Gartner and others, 2008). As vegetation cover and soil properties return to pre-fire conditions, the threat of debris-flow activity decreases with time elapsed since wildfire. Conversely, the hazards from flashflooding may persist for several years after wildfire.

Finally, this work is preliminary and is subject to revision. It is being provided due to the need for timely "best science" information. The assessment is provided on the condition that neither the U.S. 
Geological Survey nor the Unites States Government may be held liable for any damages resulting from the authorized or unauthorized use of the assessment.

\section{Summary and Conclusions}

This hazard assessment characterizes the post-fire debris-flow hazards that may exist within and below the 2013 Rim fire, Stanislaus National Forest and Yosemite National Park, Calif. We use geospatial data related to basin morphometry, burn severity, soil properties, and rainfall characteristics to estimate the probability and the predicted volume of debris flows that may occur in response to a 10 -yr recurrence interval rainstorm. We have identified that probabilities of debris-flow occurrence in response to the design rainstorm are relatively low throughout the burn area, with only 124 of the 1,238 defined basins having a probability of debris-flow greater than 40 percent. However, the volume model predicts that if debris flows are initiated, the consequences could be significant, as potential debris flows may be large. Debris-flow modeling predicts that 88 of the 1,238 basins are capable of producing debris flows with volumes greater than $10,000 \mathrm{~m}^{3}$. Combining the probability and volume models into a combined hazard ranking indicates that 300 basins were of the moderate threat of post-fire debris-flow activity, obtaining a score between 4 and 6 out of a possible 9.

Large predicted volumes (greater than $10,000 \mathrm{~m}^{3}$ ) and moderate relative hazard rankings (cumulative scores between 4 and 6 out of a possible 9) identified by the spatially distributed models indicate a relatively high likelihood (greater than 40 percent) of debris-flow impact to infrastructure, including roads, trails, and power utilities as well as other important natural and cultural resources located both within and downstream of the burn area. We recommend that residents and visitors remain vigilant and take responsible actions to prevent injury or loss of life from post-fire debris flows and flash floods that may occur in response to high-intensity rainfall during short-lived summer convective thunderstorms and longer-duration winter storms. Specifically, residents, tourists, and motorists should adhere to evacuation guidelines and closures of roads, trails, and open space.

\section{References Cited}

Benda, L.E., and Cundy, T.W., 1990, Predicting deposition of debris flows in mountain channels: Canadian Geotechnical Journal, v. 27, p. 409-417.

Bonnin, G.M., Martin, D., Lin, B., Parzybok, T., Yekta, M., and Riley, D., 2006, Precipitation frequency atlas of the United States: Silver Spring, Md., National Weather Service, National Oceanic and Atmospheric Administration (NOAA) atlas 14, v. 1, version 5, accessed July 30, 2013, at http://hdsc.nws.noaa.gov/hdsc/pfds/.

Campbell, R.H, 1975, Soil slips, debris flows, and rainstorms in the Santa Monica mountains and vicinity, southern California: U.S. Geological Survey Professional Paper 851, 55 p.

Cannon, S.H., Boldt, E.M., Laber, J.L., Kean, J.W., and Staley, D.M., 2011, Rainfall intensityDuration thresholds for postfire debris-flow emergency-response planning: Natural Hazards, v. 59, no. 1, p. 209-236.

Cannon, S.H., and DeGraff, J., 2009, The increasing wildfire and post-fire debris-flow threat in western USA, and implications for consequences of climate change, chap. 9 of Sassa, K. and Canuti, P., eds., Landslides_-Disaster risk reduction: Springer, Berlin, p. 177-190.

Cannon, S.H., and Gartner, J.E., 2005, Wildfire-related debris flow from a hazards perspective, chap. 15 of Jakob, M., and Hungr, O., eds., Debris-flow hazards and related phenomena: Chichester, U.K., Springer-Praxis Books in Geophysical Sciences, p. 321-344. 
Cannon, S.H., Gartner, J.E., Rupert, M.G., Michael, J.A., Rea, A.H., and Parrett, Charles, 2010, Predicting the probability and volume of postwildfire debris flows in the intermountain Western United States: Geological Society of America Bulletin, v. 122, p. 127-144.

Cannon, S.H., Gartner, J.E., Wilson, R., Bowers, J., and Laber, J., 2008, Storm rainfall conditions for floods and debris flows from recently burned areas in southwestern Colorado and southern California: Geomorphology, v. 96, no. 3-4, p. 250-269.

Cannon, S.H., and Michael, J.A., 2011, Emergency assessment of postwildfire debris-flow hazards for the 2011 Motor Fire, Sierra and Stanislaus National Forests, California: U.S. Geological Survey Open-File Report 2011-1251, 10 p., http://pubs.usgs.gov/of/2011/1251/.

Eaton, E.C., 1935, Flood and erosion control problems and their solution: Proceedings of the American Society of Civil Engineers, v. 62, no. 8, p. 1,302-1,362.

Gabet, E., and Sternberg, P., 2008, The effects of vegetative ash on infiltration capacity, sediment transport, and the generation of progressively bulked debris flows: Geomorphology, v. 10, no. 4, p. 666-673.

Gartner, J.E., Cannon, S.H., Santi, P., and Dewolfe, V., 2008, Empirical models to predict the volumes of debris flows generated by recently burned basins in the western U.S.: Geomorphology, v. 96, no. 3-4, p. 339-354.

Gartner, J.E., Cannon, S.H., and Santi, P.M, 2011, Implementation of post-fire debris-flow hazard assessments along drainage networks, southern California, U.S.A., in Genevois, R., Hamilton, D.L., and Prestininzi, A., eds., Proceedings of the Fifth International Conference on Debris Flow Hazards Mitigation/Mechanics, Prediction, and Assessment Padua, Italy, June 7-11, 2011, Italian Journal of Engineering Geology and Environment-Book: Casa Editrice Universita La Sapienza, Rome, p. $855-863$.

inciweb.org, 2013, Rim fire: InciWeb, accessed September 2013, at http://www.inciweb.org/incident/3360.

Kean, J.W., Staley, D.M., and Cannon, S.H., 2011, In situ measurements of post-fire debris flows in southern California - Comparisons of the timing and magnitude of 24 debris-flow events with rainfall and soil moisture conditions: Journal of Geophysical Research, v. 116, F4:F04019.

Larsen, I.J., MacDonald, L.H., Brown, E., Rough, D., Welsh, M.J., Pietraszek, J.H., Libohova, Z., de Dios Benavides-Solorio, J., and Schaffrath, K., 2009, Causes of post-fire runoff and erosion-Water repellency, cover, or soil sealing?: Soil Science Society of America Journal, v. 73, no. 4, p. 1,3931,407 .

Martin, D.A., and Moody, J. A., 2001, Comparison of soil infiltration rates in burned and unburned mountainous watersheds: Hydrological Processes, v. 15, p. 2,893-2,903.

Moody, J.A., and Martin, D.A., 2001, Initial hydrologic and geomorphic response following a wildfire in the Colorado Front Range: Earth Surface Processes and Landforms, v. 26 no. 10, p. 1,049-1,070.

McPhee, J.A., 1989, The control of nature: New York, Farrar, Straus and Giroux, 272 p.

Schwartz, G.E., and Alexander, R.B., 1995, Soils data for the conterminous United States derived from the NRCS State Soil Geographic (STATSGO) Database: U.S. Geological Survey Open-File Report 95-449, accessed July 2013, at http://water.usgs.gov/GIS/metadata/usgswrd/XML/ussoils.xml.

Shakesby, R.A., and Doerr, S.H., 2006, Wildfire as a hydrological and geomorphological agent: EarthScience Reviews, v. 74, no. 3-4, p. 269-307.

Stock, J.D., and Dietrich, W.E., 2003, Valley incision by debris flows-Evidence of a topographic signature: Water Resources Research, v. 39, no. 4, 1089.

Staley, D.M., Kean, J.W., Cannon, S.H., Schmidt, K.M., and Laber, J.L., in press, Objective definition of rainfall intensity-Duration thresholds for the initiation of post-fire debris flows in southern California: Landslides, p. 1-16. 
Tillery, A.C., Matherne, A.M., 2013, Postwildfire debris-flow hazard assessment of the area burned by the 2012 Little Bear fire, south-central New Mexico: U.S. Geological Survey Open File Report 20131108, 15 p., 3 plates, at http://pubs.usgs.gov/of/2013/1108/.

Tillery, A.C., Matherne, A.M., and Verdin K.L., 2012, Estimated probability of postwildfire debris flows in the 2012 Whitewater-Baldy Fire burn area, southwestern New Mexico: U.S. Geological Survey Open-File Report 2012-1188, 11 p., 3 plates, at http://pubs.usgs.gov/of/2012/1188/.

Verdin, K.L., Dupree, J.A., Elliot, J.G., 2012, Probability and volume of potential postwildfire debris flows in the 2012 Waldo Canyon Burn Area near Colorado Springs, Colorado: U.S. Geological Survey Open-File Report 2012-1158, 8 p., at http://pubs.usgs.gov/of/2012/1158/. 